\title{
Circular Migration Between Georgia and Turkey: Is Triple Win a Solution for Illegal Employment?
}

\author{
Prof. Dr. Adem Kalça (Karadeniz Technical University, Turkey) \\ Y1lmaz Onur Ari (Bayburt University, Turkey)
}

\begin{abstract}
Migrants who come from Georgia is one of the main issues in Turkey's migration policy. Just like other Eastern Bloc Countries, after socialism collapsed in Georgia, its economy had many problems and impoverished many Georgia citizens. Therefore, Georgian people migrate to Turkey in a circular way in order to work or trade with the strategy for survival. Unfortunately, circular movements from Georgia to Turkey are not subject to a program and it causes many problems like illegal employment, bad living conditions and lack of migrants' skill and knowledge development.

The concept of circular migration and the effects of triple win solution are discussed theoretically in this study. Also a swot analysis of demographic and labor market of autonomous border region of Georgia is made and both negatives and positives of Georgian circular migration to Eastern Black Sea Region are analyzed.

According to the results, it's emphasized that a circular migration program between Georgia and Turkey is necessary to practice the triple win scenario. Triple win scenario supports many economic benefits for all three elements of circular migration, namely home and host countries and the migrants themselves, provided that there is a regulated circular migration. Several measures can be taken to prevent unregistered employment and poor working conditions of migrants, the most importantly the spontaneous circular movement between Georgia and Turkey can be transformed to programmed circular movement.
\end{abstract}

\section{Introduction}

Circular migration is a temporary and repetitive movement between home and host countries, which migrants mostly do for working, especially in agriculture, tourism and construction sectors.

Triple win scenario supports many economic benefits for all three elements of circular migration, namely home and host countries and the migrants themselves, provided that there is a regulated circular migration. Unfortunately, circular migration from Georgia to Turkey is not regulated and programmed so it creates many problems such as unregistered employment, bad living standards and lack of knowledge and new skills of migrants.

Thanks to circular migration programmes, circular migrants fill labor shortages in host countries, remittances sent home by migrants contribute to the economic development of home countries. Migrants gain new knowledges and skills. Also they can use them when they go back to their countries. Circular migration reduces the brain drain and encourage transfer of skills.

In some cases, circular migration may create some problems and bring negatives to migrants. Potential problems in the host country include lack of employment protection and opportunities for integration, and exposure to antimigrant attitudes and behaviors.

In this study it's emphasized that a circular migration program between Georgia and Turkey is necessary to practice the triple win scenario. Also its economic effects with advantages and disadvantages and the future of this movement were discussed.

\section{Definition and Terminology of Circular Migration}

International migrations include many processes such as the decision of migration and return. Circular migration is the result of the range of decisions and arises from social networks between two places (Haug, 2012). In Figure1 , there are some preferences about migrants' decisions. While some of the migrants never migrate, some of them can choose to live in destination country permanently. Some of them are return migrants, they stay and work in destination country and return to their homeland permanently. Circular migration is a temporary form of return migration. 


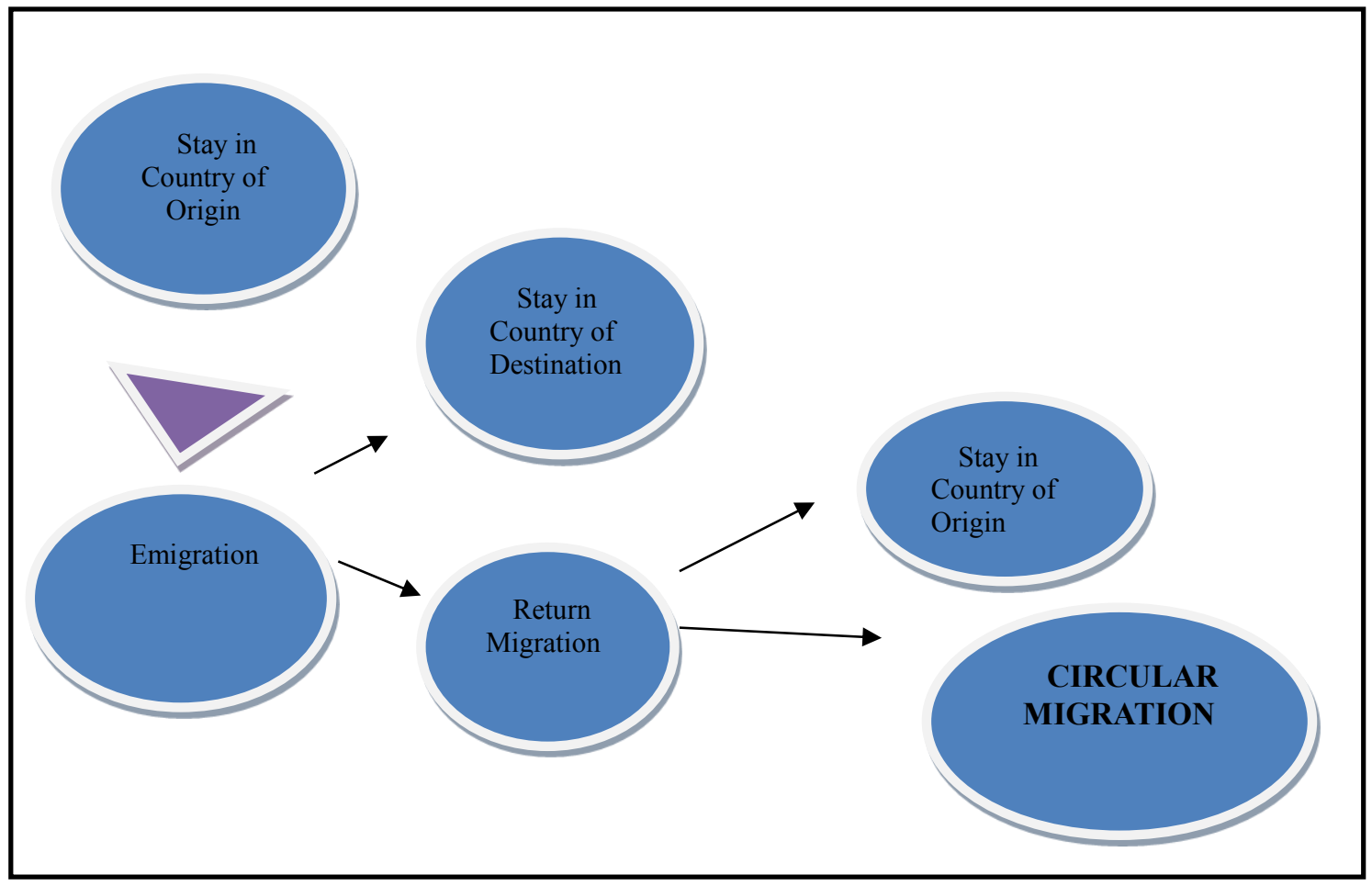

Figure-1: Decision to Migrate and to Return-Circular Migration Source: Haug, 2012: 8

Circular migration is characterized as a back-and-forth movement which raises the development of country of origin and country of destination as well as migrant workers (Government Offices of Sweden, 2010). Constant et al. (2012) defined circular migration as "systematic and regular migrant movements between source and destination countries in order to work". Both skilled and unskilled workers migrate circularly. In literature circular migration has many synonyms: repeat, rotating, cyclical, circuit, shuttling.

Circular migration is related to the temporary movements of migrants, so sometimes it is also used "temporary migration". Although returning to home is emphasized in European Migration Network definitions, contrary to temporary migration, circularity is defined as "legal migration which is repeated between two or more countries by the same worker". Another difference is about the length of stay. Seasonal migration from 3 months to 9 months is considered as "circular migration" (Kazmierkiewicz, 2013).

\section{Spontaneous Circular Migration}

Spontaneous circular migration is also called "embedded circular migration" migration type occurs in borders where there are frequent interactions and frequent circular movements. Grassroots patterns of mobility- often unmanaged- may characterize them. It happens more to countries with close ties such as Lebanon and Syria, and Nepal and India (Wickramasekara, 2011).

Cultural ties between country of origin and country of destination enables circular migration to shape. Mutual interactions between both countries and people, bilateral trade of goods and transactions by citizens who live in borderline make these movements circular. Besides, these mutual relationships sometimes changed the national politics of governments. Changes in visa requirement between Turkey and Syria is a good example. Similarly, this situation can be seen between Bulgarian and Turkish citizens in Edirne, which is a border town in Turkey (Ozkul, 2011).

Some obstacles may impede people to migrate across the border, in that case circular migration is in a spontaneous way. For example, political and military tension between two countries. Obstacles may result with tight migration politics and forced border controls, so this situation blocks circular migration and doesn't leave no alternative except permanent migration (Cassarino, 2008). As a result, spontaneous circular migration can be limited with law or encourage, although it is considered as a natural migration movement. Some general factors which make the circular migration easy are low communication and transportation costs, to eliminate the entry barriers for destination country, to give residence permit in destination country for a long time, liberal conditions for allowing naturalization and dual citizenship, simplified processes for entry permits for repeat migrants, portability of pensions and tax relief that encourages circularity, for example. Best facilitating factor for spontaneous circular migration is to give migrants a legal status, which allows for increased mobility with no risk (Herveus, 2014). 
Circular migration is promoted as a "triple win scenario" which provides benefits to origin country, destination country and migrants, and it is considered as a development-friendly mechanism of labor migration. After the importance of remittances in world economics was understood particularly, this type of temporary migration became popular. The worldwide value of remittances has increased incrementally since $90 \mathrm{~s}$ and has exceeded over 105 billion dollars annually. Today this increase continues. USA estimated that the total value of global remittances was approximately 232 billion dollars in 2006, and it will increase if unofficial flows are added. In addition to this, "The Communication on Migration and Development Report" published by the European Commission in 2005, proposes that circular migration could play a crucial role in fostering the transfer of skills to the developing world. Finally, in 2005 the European Commission addressed circular migration in a second document named "Policy Plan on Legal Migration" outlining how circular migration would make it even easier for employers to hire temporary labor migrants and identifying possible measures that could enable circular migration programs (Bassina, 2012).

\begin{tabular}{|l|l|l|l|l|}
\hline Migrant & $\begin{array}{l}\text { - Increased earnings and remittances } \\
\text { - Improved skills } \\
\text { - Improved earning possibilities upon return through } \\
\text { investment }\end{array}$ \\
\hline Country of & $\begin{array}{l}\text { - Fulfillment of labor shortages } \\
\text { - Minimised training costs if same migrants are hired } \\
\text { seasonally. } \\
\text { - Increased domination over workers. }\end{array}$ \\
\hline Country of & $\begin{array}{l}\text { - Access to destination country's labor markets. } \\
\text { - Inflow of remittances } \\
\text { - Replacing brain drain with brain circulation } \\
\text { - Benefits from investments of migrant workers }\end{array}$ \\
\hline Origin
\end{tabular}

Figure-2: Triple-Win: Positive Effects of Circular Migration on Country of Destination, Country of Origin and Migrants Source: Sana, 2012: 38

In Figure-2, we can say that all the three elements of triple win scenario, namely country of origin, country of destination and migrants gain many advantages thanks to circular migration. Circular migration provides the connection between migration and development in country of origin by supporting return investment and human capital. It is considered as a supplementary policy to remittances and diaspora investments. From this perspective, main policy goal is to maximize the potential benefit of returning to country of origin and to create a synergy between remittances and return investments. If we combine all these approaches, circular migration is considered as an ideal solution to decrease illegal migration. Providing the migrants legally to the labor market lowers the number of migrants who work illegally in country of destination.

\section{Circular Migration: The Case of Georgia and Turkey}

"Migrants who come from Georgia" is one of the main issues in Turkey's migration policy. Just like other Eastern Bloc Countries, after socialism collapsed in Georgia, its economy had many problems and impoverished many Georgia citizens. Therefore, Georgian people migrate to Turkey in order to work or trade with the strategy for survival (Ulukan and Ulukan, 2012).

When visa regime is analyzed between Turkey and Georgia in terms of migration policy, a liberal policy seems prioritized. Sarp Border Gate was firstly opened in 1989 and 1-month tourist visa was acknowledged for Georgian citizens. With the agreement between two countries in 1996, visa was started to get at border gate. In 2006 visa regime became more liberal. According to that bilateral agreement, citizens of both Georgia and Turkey had the right to enter and exit reciprocally within 90 days without any visa (Ulukan and Ulukan, 2012). Table-1 shows the number of Georgian people who entered Turkey between 2000 and 2014. It's seen that there is an increase in number of Georgian people in Turkey after 2006 agreement. 


\begin{tabular}{|c|c|c|c|c|c|c|}
\hline Years & By Plane & $\begin{array}{c}\text { By } \\
\text { Highway }\end{array}$ & By Train & By Ship & Total & $\begin{array}{c}\text { Share in the total } \\
\text { amount of foreign } \\
\text { visitors (\%) }\end{array}$ \\
\hline 2000 & 10.034 & 166.973 & 314 & 2.330 & 179.651 & 1.72 \\
\hline 2001 & 8.906 & 152.616 & 421 & 2.115 & 164.058 & 1.41 \\
\hline 2002 & 10.207 & 149.393 & 77 & 1.698 & 161.375 & 1.22 \\
\hline 2003 & 8.082 & 157.852 & 57 & 1.920 & 167.911 & 1.20 \\
\hline 2004 & 11.294 & 221.161 & 36 & 2.446 & 234.937 & 1.34 \\
\hline 2005 & 16.698 & 348.461 & 66 & 2.113 & 367.338 & 1.74 \\
\hline 2006 & 27.709 & 517.910 & 48 & 3.661 & 549.328 & 2.77 \\
\hline 2007 & 41.131 & 584.260 & 69 & 5.519 & 630.979 & 2.70 \\
\hline 2008 & 52.849 & 771.295 & 64 & 5.976 & 830.184 & 3.15 \\
\hline 2009 & 44.126 & 945.014 & 52 & 6.189 & 995.381 & 3.68 \\
\hline 2010 & 42.041 & 1.063 .906 & 59 & 6.187 & 1.112 .193 & 0.21 \\
\hline 2011 & 55.203 & 1.090 .721 & 21 & 6.716 & 1.152 .661 & 3.66 \\
\hline 2012 & 51.992 & 1.346 .712 & 3 & 6.175 & 1.404 .882 & 4.42 \\
\hline 2013 & 68.169 & 1.694 .105 & 12 & 7.161 & 1.769 .447 & 5.07 \\
\hline 2014 & 85.010 & 1.661 .591 & 1 & 8.687 & 1.755 .289 & 4.76 \\
\hline
\end{tabular}

Table-1: Number of Georgian Citizens Who Entered to Turkey Source: (Kültür ve Turizm Bakanlığl, 2015)

Distribution of Georgian citizens with respect to border gates and provinces is shown at Table-2:

\begin{tabular}{|c|c|c|c|c|c|c|c|c|c|c|c|}
\hline & $\begin{array}{c}\text { Artvin } \\
(\text { Sarp})\end{array}$ & $\begin{array}{c}\text { Hopa } \\
(\mathrm{S})\end{array}$ & $\begin{array}{c}\text { Rize } \\
(\mathrm{S})\end{array}$ & $\begin{array}{c}\text { Trabzon } \\
(\mathrm{S})\end{array}$ & $\begin{array}{c}\text { Trabzon } \\
(\mathrm{P})\end{array}$ & $\begin{array}{c}\text { Ordu } \\
(\mathrm{S})\end{array}$ & $\begin{array}{c}\text { Ünye } \\
(\mathrm{S})\end{array}$ & $\begin{array}{c}\text { Samsun } \\
(\mathrm{S})\end{array}$ & $\begin{array}{c}\text { Samsun } \\
(\mathrm{P})\end{array}$ & $\begin{array}{c}\text { Giresun } \\
(\mathrm{S})\end{array}$ & $\begin{array}{c}\text { Ardahan } \\
(\text { Türközü})\end{array}$ \\
\hline 2001 & 115.251 & - & - & \multicolumn{2}{|c|}{1019} & 1 & - & 379 & - & & 11.198 \\
\hline 2002 & 110.546 & - & 34 & 171 & 472 & 1 & - & 214 & - & & 9.910 \\
\hline 2003 & 118.148 & 2 & 522 & 215 & 228 & 2 & - & 234 & 1 & & 8.076 \\
\hline 2004 & 176.371 & - & 444 & 96 & 381 & 8 & - & 287 & 5 & & 9587 \\
\hline 2005 & 303.456 & 19 & 166 & 178 & 244 & 4 & - & 304 & 1 & & 6.607 \\
\hline 2006 & 468.330 & 1 & 25 & 781 & 134 & 162 & - & 430 & 11 & & 5.735 \\
\hline 2007 & 533.977 & 123 & - & 841 & 365 & 203 & 102 & 670 & 9 & & 4.359 \\
\hline 2008 & 722.095 & 5 & 2 & 734 & 373 & 66 & 82 & 1.190 & 17 & & 5.010 \\
\hline 2009 & 898.344 & 5 & 7 & 686 & 393 & 26 & 16 & 1.812 & 1 & & 6.019 \\
\hline 2010 & 1.016 .169 & 84 & 1 & 557 & 442 & 80 & 24 & 2.226 & 10 & & 6.934 \\
\hline 2011 & 1.037 .124 & 15 & - & 222 & 193 & 4 & 20 & 2.897 & 10 & & 6.662 \\
\hline 2012 & 1.287 .212 & 16 & 3 & 132 & 162 & 2 & 27 & 2.731 & 20 & & 7.693 \\
\hline 2013 & 1.632 .575 & 19 & 2 & 161 & 96 & - & 29 & 2.906 & 21 & & 10.632 \\
\hline 2014 & 1.606 .376 & 66 & 5 & 230 & 238 & 3 & - & 4.304 & 17 & & 11.530 \\
\hline
\end{tabular}

Table-2: Distribution of Georgian Citizens with Respect to Border Gates and Provinces S: By Sea, P: By Plane Source: (Kültür ve Turizm Bakanlı̆̆, 2015 )

The economy of Eastern Black Sea region is based on agriculture. Hazelnut and tea are major agricultural products in this region. Georgian migrants have been working as a hazelnut and tea pickers as circular migrant workers recent years. For the last decade, thanks to the effect of non-visa entry agreement between Georgian and Turkish governments, the circularity has increased. Georgian migrants have been known "hard-working, clean and cheap", according to the owners of hazelnut and tea field. They generally cross the border legally but work illegally in agricultural areas, because they don't have a work permit. Georgian workers usually engage in low paying, dirty, dangerous and difficult jobs. Hence, Georgian migrants are preferred by landowners and landowners gain advantage by employing low paid and hard working migrants (Ulukan and Ulukan, 2010).

There is not a specific circular migration program or an agreement between Turkey and Georgia. It is completely a spontaneous movement and it may create some problems like poor working conditions, informal employment and tax losses for Turkey etc.

From Georgia's perspective circular migration programs will be necessary and beneficial for the following reasons. The sending countries (i) are relieved from any unemployment frictions and labor market imbalances, (ii) benefit tremendously from the remittances that emigrants send back, (iii) gain from new skills and knowledge that return migrants acquired abroad and bring with them upon return, (iv) through bilateral or multilateral agreements in migration, the sending countries may also strike additional agreements in trade and development and benefit even further from cooperation (Constant et al., 2012).

From Turkey's point of view circular migration programs will be also beneficial. Circular migration program can buy time for receiving country governments and employers to train native employers to meet labor shortages and can have a rejuvenating effect on aging societies. Because free movement back and forth keeps migrants' 
options open in both home and host countries, it reduces the risk of long term settlement in the host country and illegal overstaying of visas (Zimmermann, 2014).

Finally, circular migrants who return home will use new skills and knowledge they gain abroad. They may also start new businesses in their communities of origin. For sending countries, circular migration reduces the negative effects of brain drain and encourages brain circulation.

\begin{tabular}{|c|c|}
\hline Strengths & Weaknesses \\
\hline $\begin{array}{l}\text { - High rates of population growth due to } \\
\text { natural increase; } \\
\text { - } \quad \text { High population ratio of people of able- } \\
\text { bodied age and younger; } \\
\text { - } \quad \text { High countryside population ratio; } \\
\text { - } \quad \text { Cheap labour force; } \\
\text { - } \quad \text { Hard-working population; } \\
\text { - Favourable location of populated areas }\end{array}$ & $\begin{array}{l}\text { - Population migration from the region } \\
\text { and the country; } \\
\text { - High unemployment rate; } \\
\text { - } \text { High poverty rate; } \\
\text { poor quality of population social } \\
\text { - Poor quality of demographic processes } \\
\text { management; } \\
\text { - Structural and qualitative imbalances } \\
\text { between the demand on and supply of } \\
\text { labour force; } \\
\text { - Insufficient orientation of higher } \\
\text { education and vocational training } \\
\text { systems on the demands of labour } \\
\text { market; } \\
\text { Poorly developed employment } \\
\text { structure }\end{array}$ \\
\hline $\begin{array}{l}\text { Opportumities } \\
\text { - } \\
\text { infreation of strong labour market } \\
\text { - Improvement of educational system } \\
\text { meeting the demands of labour market; } \\
\text { - Training and re-training of experienced } \\
\text { personnel by state, international, and non- } \\
\text { governmental organizations, educational } \\
\text { system and private sector; } \\
\text { - Overcoming unemployment by increasing } \\
\text { private investments; } \\
\text { - Overcoming unemployment by } \\
\text { government infrastructural projects; } \\
\text { Improvement of social protection system; }\end{array}$ & $\begin{aligned} & \text { Threats } \\
&- \text { Macroeconomic instability and } \\
& \text { unfavourable investment climate; } \\
&- \text { Wide scales of external and internal } \\
& \text { migration; } \\
&- \text { Worsening of social problems; } \\
&- \text { Speculation on social problems by } \\
& \text { opposition; } \\
&- \text { Political instability }\end{aligned}$ \\
\hline
\end{tabular}

Table-3: SWOT Analysis of Demographic and Labor Market of Ajara, Georgia Source: Regional Development Strategy of the Autonomous Republic of Ajara, 2011

In Table-3, there is a swot analysis of the labor market of Ajara. Ajara is an autonomous border region of Georgia and most of the Georgian migrants come from this region to Turkey to work. It is clear that both strengths and weaknesses of Adjara labor market are opportunities for Turkish employers and labor market.

\section{Conclusion}

In this study circular migration within the scope of triple win scenario was analyzed between Turkey and Georgia. Triple win scenario supports many economic benefits for all three elements of circular migration, namely home and host countries and the migrants themselves, provided that there is a regulated circular migration. Unfortunately, circular migration from Georgia to Turkey is not regulated and programmed so it creates many problems such as unregistered employment, poor living standards and lack of knowledge and new skills of migrants.

Several measures can be taken to prevent unregistered employment and poor working conditions of migrants, the most importantly the spontaneous circular movement between Georgia and Turkey can be transformed to programmed circular movement. Thus, Turkey, Georgia and the circular migrants can gain more advantage from the effects of triple win. Turkey can minimize the loss of tax due to informal employment, Georgia can gain more remittances thanks to an equal and fair wage between domestic and migrant workers. Finally, Georgian migrant workers can gain new skills and use it when they turn back to Georgia and work in the same job.

\section{References}

- Bassina, R., 2012. "The Future of Circular and Return Migration: Integrative Migration Frameworks and Decided Return as the Only Way Forward". Major Research Paper. 
- Cassarino, J.P., 2008. "Patterns of Circular Migration in the Euro-Mediterranean Area: Implications for Policy Making”. CARIM Analytic and Synthetic Notes, 2008/29.

- Constant, A. et al., 2012. "The Economics of Circular Migration”. IZA Discussion Paper, No. 6940.

- Government Offices of Sweden, 2010. "Sweden's Committee for Circular Migration and Development”. Fact Sheet, pp.1-4.

- Haug, S., 2012. "Migration and Return Migration: The Case of Italian Migrants in Germany”. Workshop of Labor Migration and Transnationalism in Europe, Regenburg: Südost-Institut.

- Herveus, K., 2014. "The Concept of Circular Migration-Towards a Common EU Framework for Migration". Paper for the 7th Nordic Working Life Conference.

- Kazmierkiewicz, P., 2013. “Opportunities for Developing Circular Migration Schemes Between Georgia and the EU'. Georgian Young Lawyers'Association \& Caucasus Institute for Peace Democracy and Development, pp.1-19.

- Kültür ve Turizm Bakanlığ1, 2015,http://yigm.kulturturizm.gov.tr/ (Access Date: 27.12.2015)

- Newland, K., 2009. Circular Migration and Human Development. UNDP.

- Ozkul, D., 2011. Circular Migration Schemes: Renewed Interests in the Destination Countries. Best Participant Essays Series, 2011/61.

- Regional Development Strategy of the Autonomous Republic of Ajara, 2011, http://www.ajara.gov.ge/acg/files/Adjara-Development-Strategy.pdf (Access Date: 27.12.2015)

- Sana, M. W., 2012. "Circular Migration Between Guatemala and Canada: Perspectives of Guatemalan Migrant Workers". Master Thesis, University of Helsinki Faculty of Social Sciences.

- Skeldon, R., 2012. “Managing Migration for Development: Is Circular Migration the Answer?".The Whitehead Journal of Diplomacy and International Relations, pp. 21-34. 